\title{
Structural Analysis and Conceptual Seismic Design of Large-span Korean Traditional Timber Structure
}

\author{
Yeong-Min Kim \\ College of Architecture, Myongji University, Republic of Korea \\ Received February 27, 2020; Revised April 14, 2020; Accepted April 27, 2020
}

Copyright $\bigcirc 2020$ by authors, all rights reserved. Authors agree that this article remains permanently open access under the terms of the Creative Commons Attribution License 4.0 International License

\begin{abstract}
In this research, a test-bed large-span Hanok which adopts new structural system compared to the traditional structural system has been introduced, and the structural analysis and seismic design for it have been performed to test possibility as a large-span Hanok. The test-bed Hanok is composed of two parts, that is, $1^{\text {st }}$ story part and $2^{\text {nd }}$ story part. The roof structure of $1^{\text {st }}$ story part is similar to that of the traditional Hanok, but that of $2^{\text {nd }}$ story part is new-styled and different from the traditional Hanok. The two parts are joined together side by side. The largest span of this test-bed Hanok is $14.4 \mathrm{~m}$ in $1^{\text {st }}$ story part and $10.8 \mathrm{~m}$ in $2^{\text {nd }}$ story part. The structural design was done to extract optimal member size for both raw wood and glued laminated wood with satisfying safety and serviceability conditions. The comparison of the sectional area between raw wood and glulam showed that glulam required less member size than raw wood. The area ratio of the glulam compared to the raw wood is from 0.60 to 0.92 , and this shows that, glulam is more economical than raw wood in large-span Hanok from the viewpoint of the required volume of the timber which affects much in cost and construction. Conceptual seismic design methods for the test-bed large-span Hanok were proposed and the structural characteristics of each method were discussed. The proposed method is summarized as addition of shear wall, reinforcing existing shear wall and isolating the basement of the structure from the ground.
\end{abstract}

Keywords Korean Traditional Timber Structure, Large-span Hanok, Structural Analysis, Seismic Design

\section{Introduction}

The Korean traditional timber structure is called Hanok. It is generally said that Hanok has history of about 2,000 years. The main structural characteristic of Hanok is that it utilizes post and beam structural system. Generally, the gravity load is resisted by post and beam frame, and the lateral load is resisted by walls. The wall used in Hanok is combined with wall-frame system, which is somewhat like infilled wall, where wall is infilled to the peripheral wood frame. Traditionally, the connection between post and beam was made by mortise and tenon joint of only wood. Nowadays, new-styled Hanok is appeared to accommodate modern life-style and here, the connection type between main structural members is made steel joints to accelerate the construction process. Fig. 1A shows example of a traditional style Hanok, and Fig. 1B shows example of a modernized new-styled Hanok.

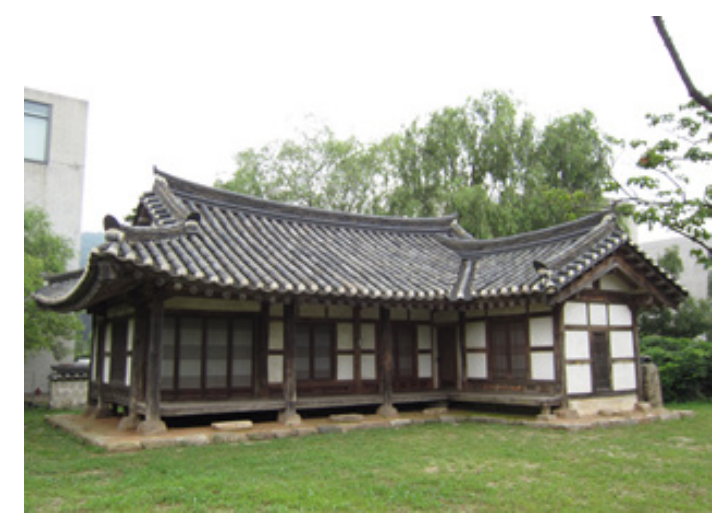

(A). Traditional style Hanok

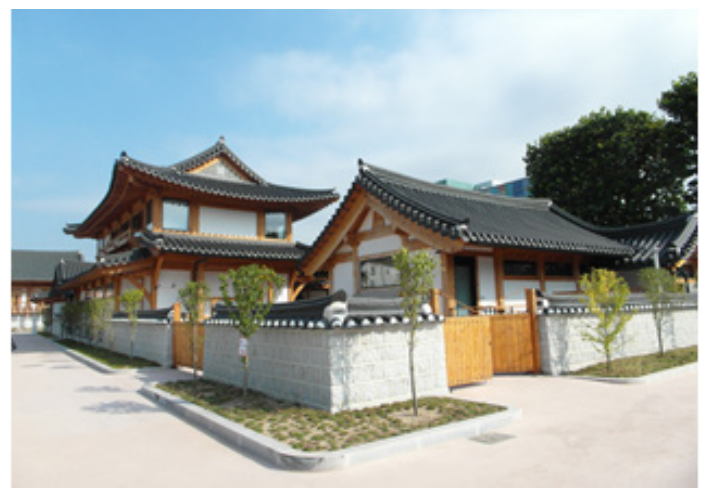

(B) Modernized new-styled Hanok

Figure 1. Korean traditional timber house, Hanok 
To expand the supply of Hanok, the usage of it should be diversified. Hanok has been used mainly for residential purpose. The span between columns in residential house is generally $2.4 \mathrm{~m} \sim 4.2 \mathrm{~m}$. To utilize Hanok as a public usage, such as community center, school, police station, library, museum and so on, the span should be enlarged at least those of a reinforced concrete and a steel structure. When the span of Hanok is about $10 \mathrm{~m} \sim 20 \mathrm{~m}$, it is called large-span Hanok. Large-span Hanok cannot be acquired by just expanding the traditional Hanok with its structural system unchanged. New structural system and new material should be adopted to make large-span Hanok aesthetically acceptable, structurally safe and functionally feasible.

Various researches on timber structures have been carried out worldwide. In Korea, researches on Hanok were mainly carried out on the architectural style viewpoint, but recently researches on the structural viewpoint have been carried out briskly. To enhance life-cycle performance of timber structures, researches on moisture contents of Korean traditional timber houses have been carried out $[1,2]$. Monitoring of structural deformation for both on Korean traditional timber house and western large-span timber structures have been carried out $[3,4]$.

For Korean timber structure, static and cyclic behavior with tenon joints under lateral load has been analyzed [5] and relationship between damping ratio and vibration amplitude has been extracted by shaking table test [6]. For ancient Chinese timber structure, dynamic characteristics have been extracted by shaking table test [7]. To aid structural analysis and design of Hanok, automated structural design tools have been developed $[8,9]$. For the seismic design of Hanok, evaluation scheme for the determination of torsional irregularity and conceptual seismic isolation method have been suggested $[10,11]$.

\section{Introduction of the Test-bed Large-span Hanok}

In this chapter, a test-bed example of $14.4 \mathrm{~m}$ span Hanok is introduced, the usage of it is exhibition space and cultural center. This test-bed large-span Hanok is scheduled to be built in Yongin, Korea, 2021. The final architectural design has not confirmed yet, and can be changed. The structural analysis and seismic design for the test-bed large-span Hanok under consideration is performed to test its possibility as a large-span Hanok.

Fig. 2 shows floor plan and elevational-section of the test-bed large-span Hanok. The test-bed Hanok consists of two parts, that is, $1^{\text {st }}$ story part and $2^{\text {nd }}$ story part. The two parts are joined together side by side and to be used as a single building. The longitudinal width of the Hanok is $48 \mathrm{~m}$ and transverse width is $14.4 \mathrm{~m}$. The span between columns is $4.8 \mathrm{~m}$ in longitudinal direction, and $14.4 \mathrm{~m}$ in transverse direction. The test-bed Hanok belongs to large-span because its transverse span is more than $10 \mathrm{~m}$. The height of the $1^{\text {st }}$ story part is $9.6 \mathrm{~m}$, and that of $2^{\text {nd }}$ story part is $15.4 \mathrm{~m}$. The roof structure of $1^{\text {st }}$ story part is similar to that of the traditional Hanok, but the roof structure of the $2^{\text {nd }}$ story part is new-styled and somewhat different from that of the traditional Hanok.

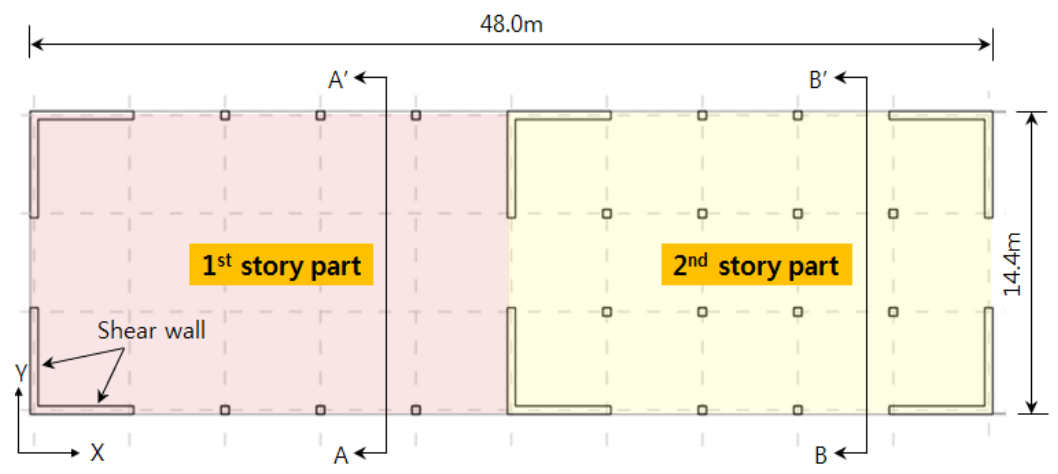

(A) Plan of $1^{\text {st }}$ floor

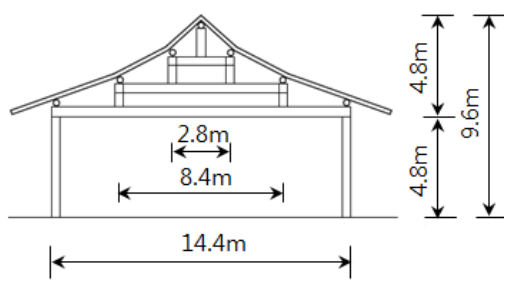

(B) A-A' section of $1^{\text {st }}$ story part

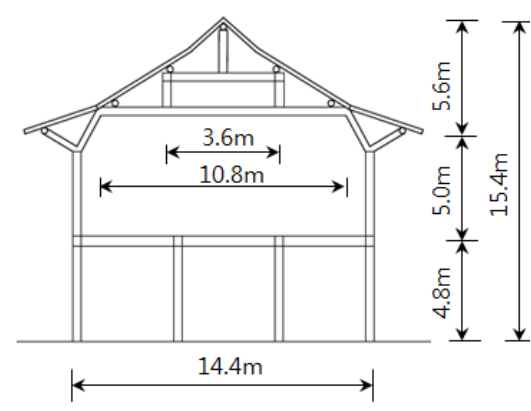

(C) B-B' section of $2^{\text {nd }}$ story part

Figure 2. Floor plan and section of the test-bed large-span Hanok 


\section{Structural Analysis of the Test-bed Large-span Hanok}

\subsection{Analysis Modeling of the Test-bed Hanok}

Fig. 3 shows analysis model of the test-bed Hanok. The structural analysis software is Midas Gen Ver.881. Fig. 3A shows three-dimensional analysis model, and Fig. 3B shows modeled elevational section of each 1 st story and 2nd story parts. Table 1 shows material properties of the analysis model. To compare the section size of the main structural members, two types of wood are used and compared, that is, raw wood and glued laminated wood. The species of raw wood is larch and its grade is 1 st and the type of glued laminated wood is $17 \mathrm{~S}-49 \mathrm{~B}$. Gravity load is composed of roof load, self-weight, and snow load. Roof load including self-weight is $4.5 \mathrm{kN} / \mathrm{m}^{2}$, snow load is $0.5 \mathrm{kN} / \mathrm{m}^{2}$.

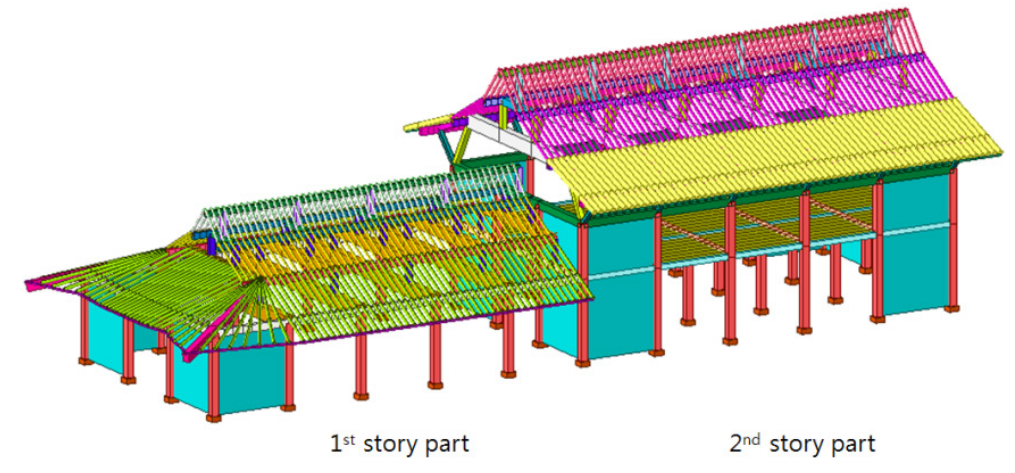

(A) Three dimensional analysis model

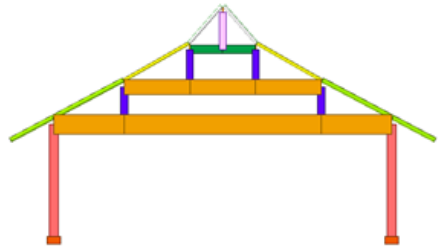

$1^{\text {st }}$ story part

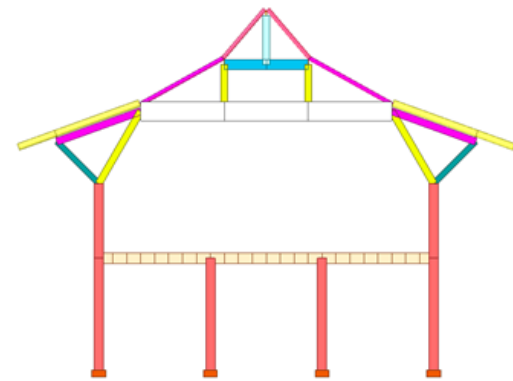

$2^{\text {nd }}$ story part

(B) Elevational section of $1^{\text {st }}$ story part and $2^{\text {nd }}$ story part

Figure 3. Structural analysis model of test-bed large-span Hanok

Table 1. Material Properties Used in Structural Analysis Model

\begin{tabular}{|c|c|c|c|c|c|c|}
\hline \multirow{2}{*}{ Wood Type } & \multicolumn{5}{|c|}{ Basic allowable stresses and modulus of elasticity (MPa) } \\
\cline { 2 - 7 } & $\mathrm{Fb}$ & $\mathrm{Ft}$ & $\mathrm{Fc}$ & $\mathrm{Fc} \perp$ & $\mathrm{Fv}$ & $\mathrm{E}$ \\
\hline $\begin{array}{c}\text { Raw wood } \\
\text { Grade 1 Larch }\end{array}$ & 8.0 & 5.5 & 9.0 & 3.5 & 1.25 & 12,200 \\
\hline $\begin{array}{c}\text { Glulam } \\
\text { 7S-49B }\end{array}$ & 10.0 & 6.5 & 7.5 & 3.5 & 2.0 & 8,000 \\
\hline
\end{tabular}




\subsection{Target Members for the Structural Design}

The target members for the structural design are main horizontal members of the test-bed Hanok. Fig. 4 shows these target members. Fig. 4A and Fig. 4B show target members of the 1st story part both in transverse $(\mathrm{Y})$ and longitudinal(X) direction, respectively. There are three members for the structural design in 1st story part in $\mathrm{Y}$ direction, such as, main girder, middle girder and celler girder, the span of which are $14.4 \mathrm{~m}, 8.4 \mathrm{~m}$ and $2.8 \mathrm{~m}$ respectively. And there are four members for the structural design in 1st story part in $\mathrm{X}$ direction, such as, ridge, middle-upper purlin, middle-lower purlin and column purlin, the span of which are identical, that is, $4.8 \mathrm{~m}$.

Fig. 4C and Fig. 4D show target members of the 2nd story part both in transverse $(\mathrm{Y})$ and longitudinal $(\mathrm{X})$ direction, respectively. There are two members for the structural design in 2nd story part in $\mathrm{Y}$ direction, such as, main girder and celler girder, the span of which are $10.8 \mathrm{~m}$ and $3.6 \mathrm{~m}$ respectively. And there are four members for the structural design in 2nd story part in $\mathrm{X}$ direction, such as, ridge, middle purlin, column-inner purlin and column-outer purlin, the span of which are identical, that is, $4.8 \mathrm{~m}$. The largest member span of the 1st story part is $14.4 \mathrm{~m}$ and that of the 2nd story part is $10.8 \mathrm{~m}$, both lay in $\mathrm{Y}$ direction.

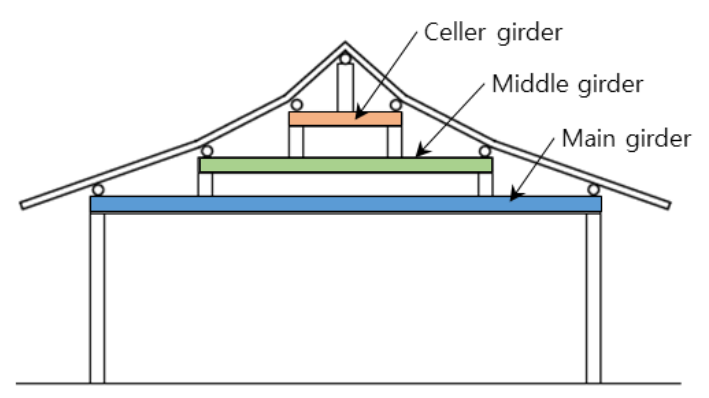

(A) Main horizontal members in Y direction of $1^{\text {st }}$ story part

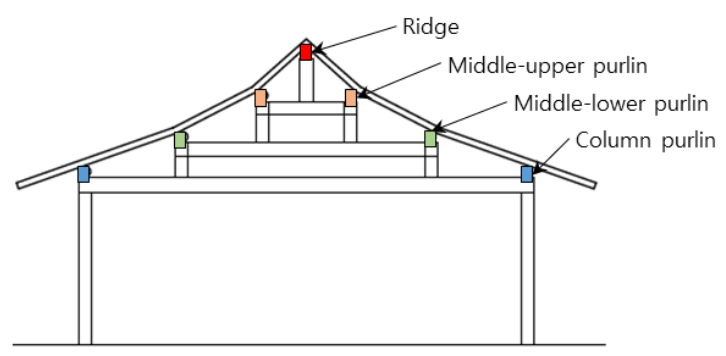

(B) Main horizontal members in $\mathrm{X}$ direction of $1^{\text {st }}$ story part

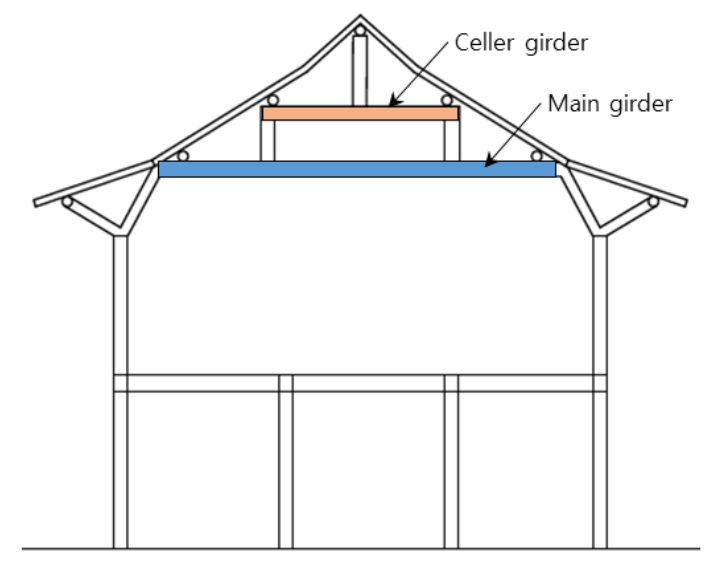

(C) Main horizontal members in Y direction of $2^{\text {nd }}$ story part

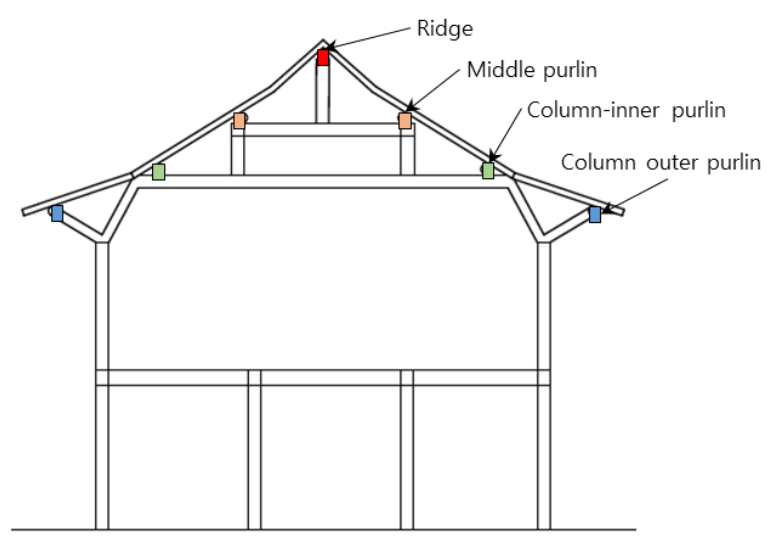

(D) Main horizontal members in X direction of $2^{\text {nd }}$ story part

Figure 4. The target members for the structural design

\subsection{Results of the Structural Analysis}

Static analysis under gravity load was performed for the test-bed large span Hanok. Fig. 5 shows deformed shape of the analysis model. Fig. 5A shows deformed shape from the isometric view, and Fig. 5B shows deformed shape from the top view. The maximum deformation is appeared in the cantilevered corner of the roof.

Fig. 6 shows member force diagrams of the elevational section of the 1st story part and 2nd story part. Here, bending moment diagram and shear force diagram are shown. As expected the maximum bending moment of the horizontal member appears at the center of the member, and that of the shear force appears at the extreme ends of the member. 


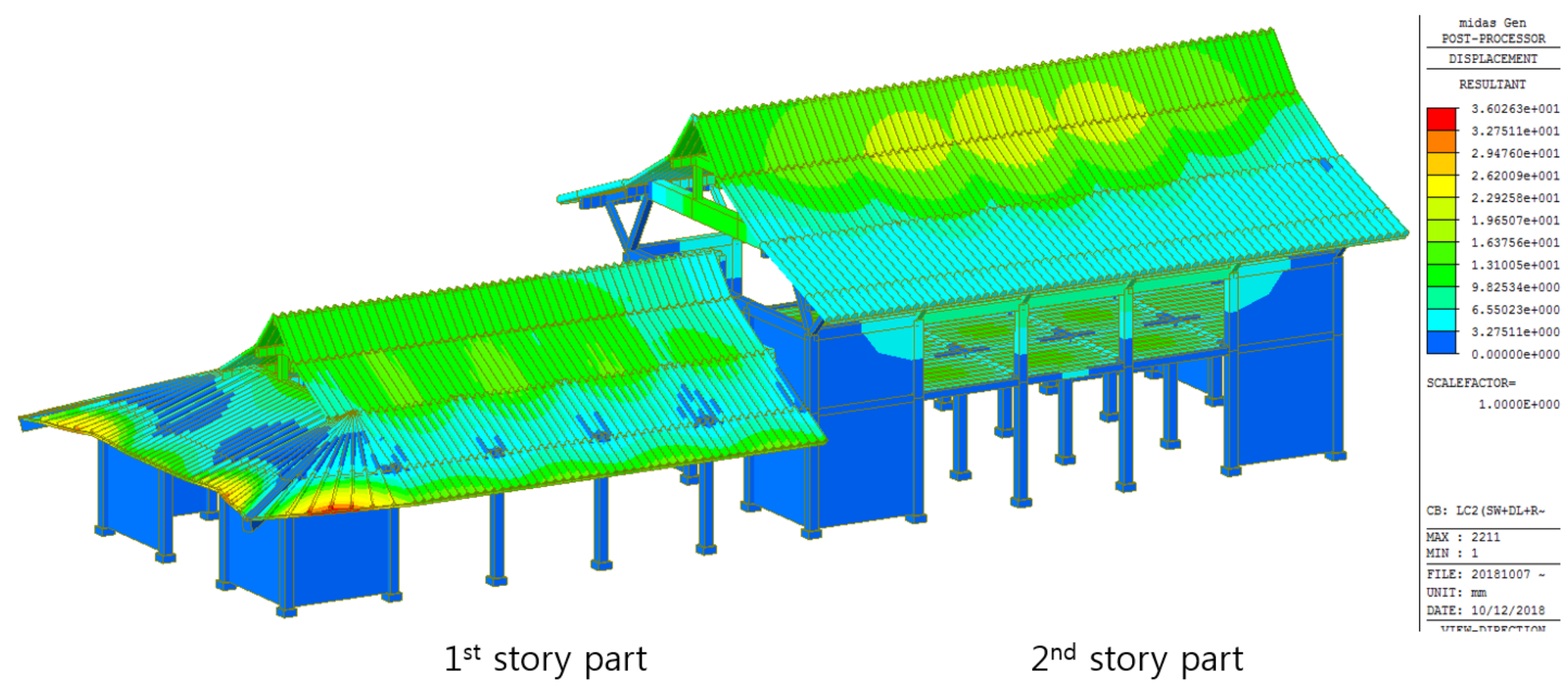

(A) Deformed shape under gravity load from isometric view 


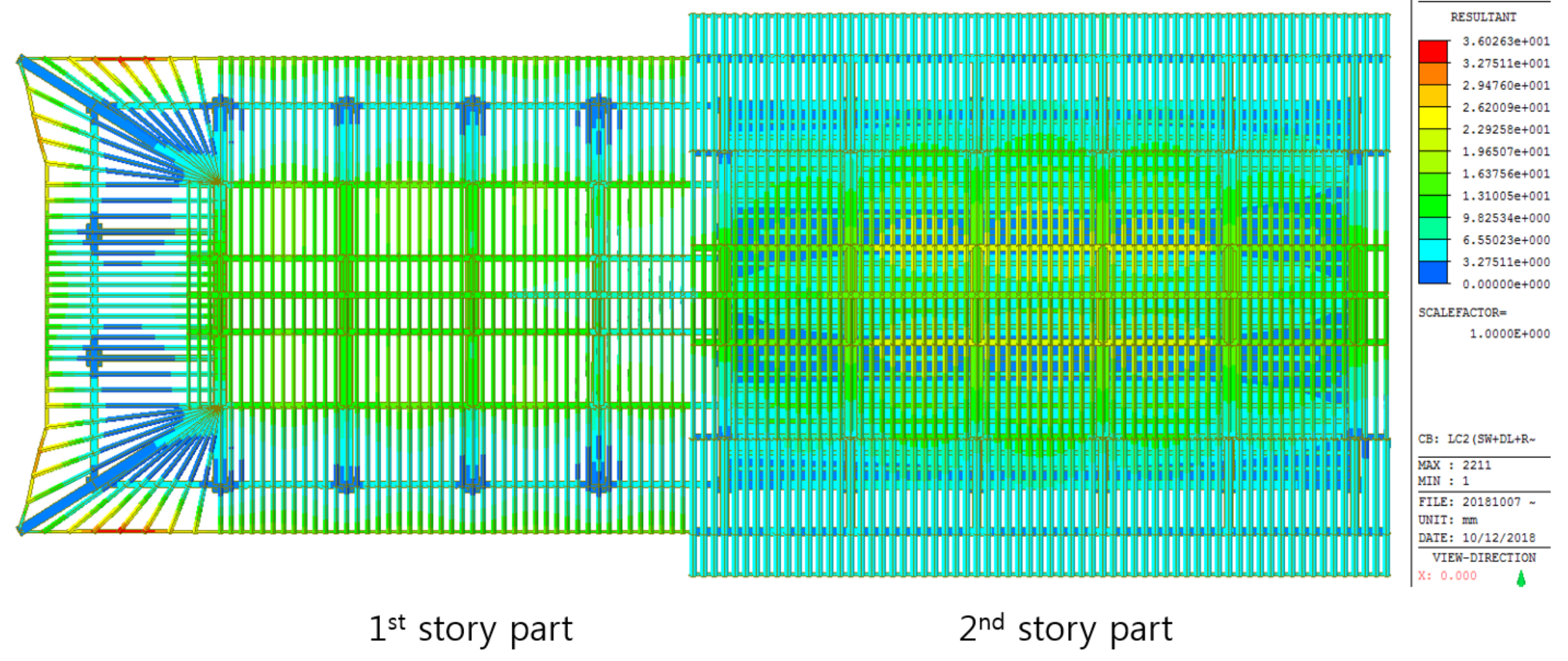

(B) Deformed shape under gravity load from top view

Figure 5. Deformed shape of test-bed large-span Hanok 


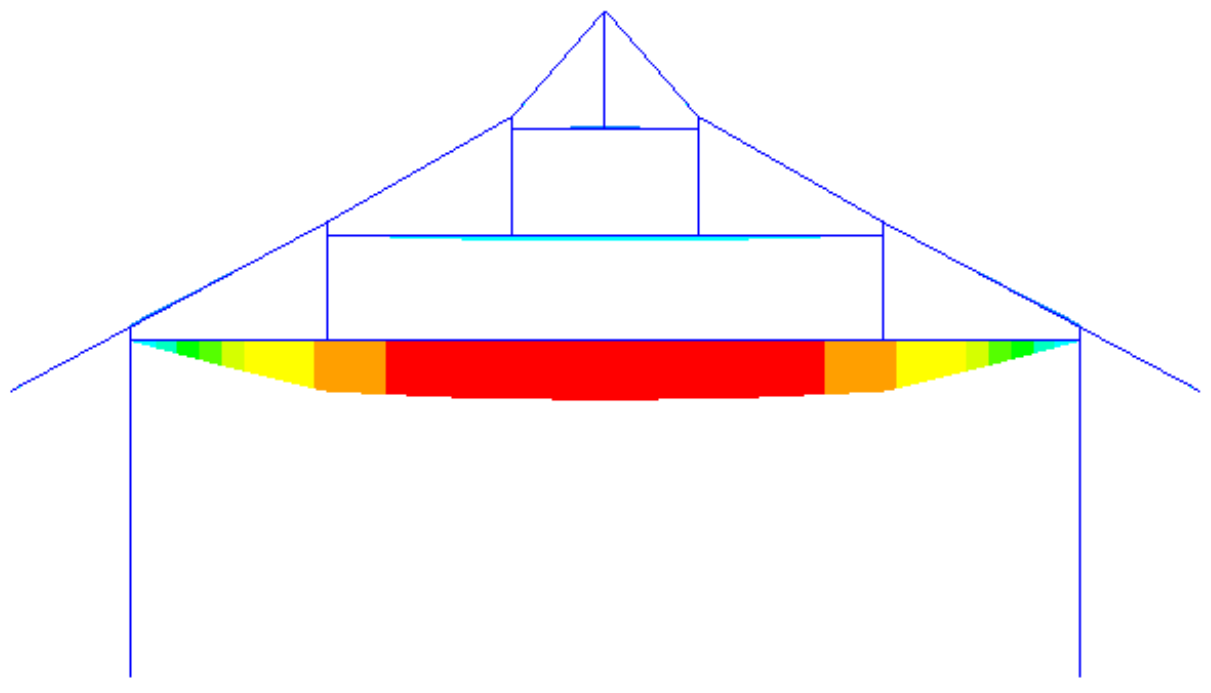

midas Gen POST-PROCESSOR BEAM DIAGRAM

MOMENT-y

$1.25428 \mathrm{e}+002$

$1.13217 \mathrm{e}+002$

$1.01007 e+002$

$8.87968 \mathrm{e}+001$

$7.65865 e+001$

$6.43761 \mathrm{e}+001$

$5.21658 \mathrm{e}+001$

$3.99555 \mathrm{e}+001$

$2.77451 \mathrm{e}+001$

$1.55348 \mathrm{e}+001$

$0.00000 e+000$

$-8.88587 e+000$

$\mathrm{CB}: \mathrm{LC} 2(\mathrm{SW}+\mathrm{DL}+\mathrm{R} \sim$

MAX : 343

MIN : 400

FILE: 20181007

UNIT: $\mathrm{kN} \cdot \mathrm{m}$

DATE: $04 / 13 / 2020$

VIEW-DIRECTION

(A) Bending moment diagram of $1^{\text {st }}$ story part

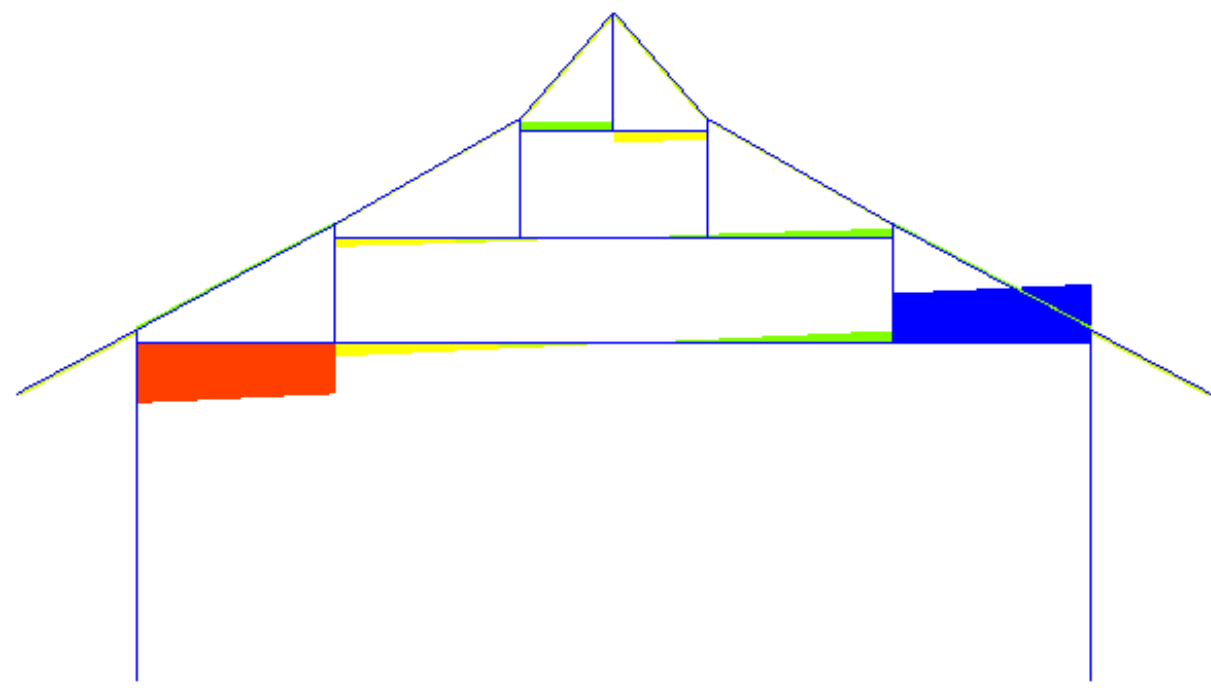

midas Gen POST-PROCESSOR BEAM DIAGRAM

SHEAR- $z$

$3.88925 e+001$

$3.18211 \mathrm{e}+001$

$2.47497 \mathrm{e}+001$

$1.76783 e+001$

$1.06069 \mathrm{e}+001$

$0.00000 e+000$

$-3.53586 \mathrm{e}+000$

$-1.06073 e+001$

$-1.76786 e+001$ $-2.47500 \mathrm{e}+001$

$-3.18214 \mathrm{e}+001$

$-3.88928 \mathrm{e}+001$

CB: $\mathrm{LC} 2(\mathrm{SW}+\mathrm{DL}+\mathrm{R} \sim$

MAX : 344

MIN : 342

FILE: 20181007

UNIT: $k N$

DATE: $04 / 13 / 2020$

VIEW-DIRECTION $\mathrm{X}: 1.000$

(B) Shear force diagram of $1^{\text {st }}$ story part 


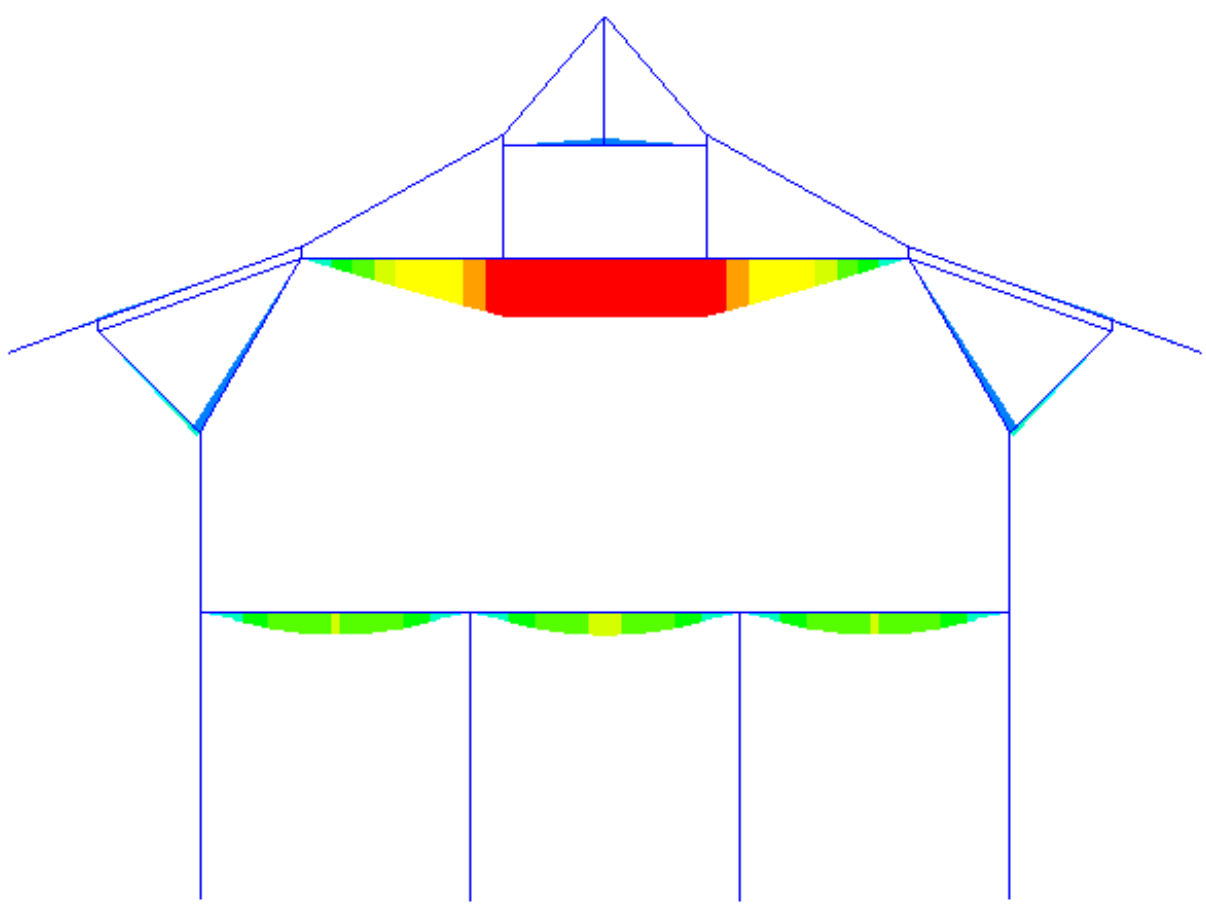

midas Gen POST-PROCESSOR BEAM DIAGRAM

MOMENT-y

$1.52518 \mathrm{e}+002$

$1.36468 \mathrm{e}+002$

$1.20417 \mathrm{e}+002$

$1.04366 \mathrm{e}+002$

8. $83150 \mathrm{e}+001$

$7.22641 \mathrm{e}+001$

$5.62133 \mathrm{e}+001$

$4.01624 \mathrm{e}+001$

2. $41116 \mathrm{e}+001$

$8.06072 \mathrm{e}+000$

$0.00000 \mathrm{e}+000$

$-2.40410 \mathrm{e}+001$

CB: $\mathrm{LC} 2(\mathrm{SW}+\mathrm{DL}+\mathrm{R} \sim$

MAX : 196

MIN : 276

FILE: 20181007

UNIT: $\mathrm{kN} \cdot \mathrm{m}$

DATE: 04/13/2020

VIEW-DIRECTION

$\mathrm{X}: 1.000$

Y : 0.000

Z: 0.000

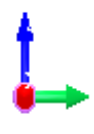

(C) Bending moment diagram of $2^{\text {nd }}$ story part

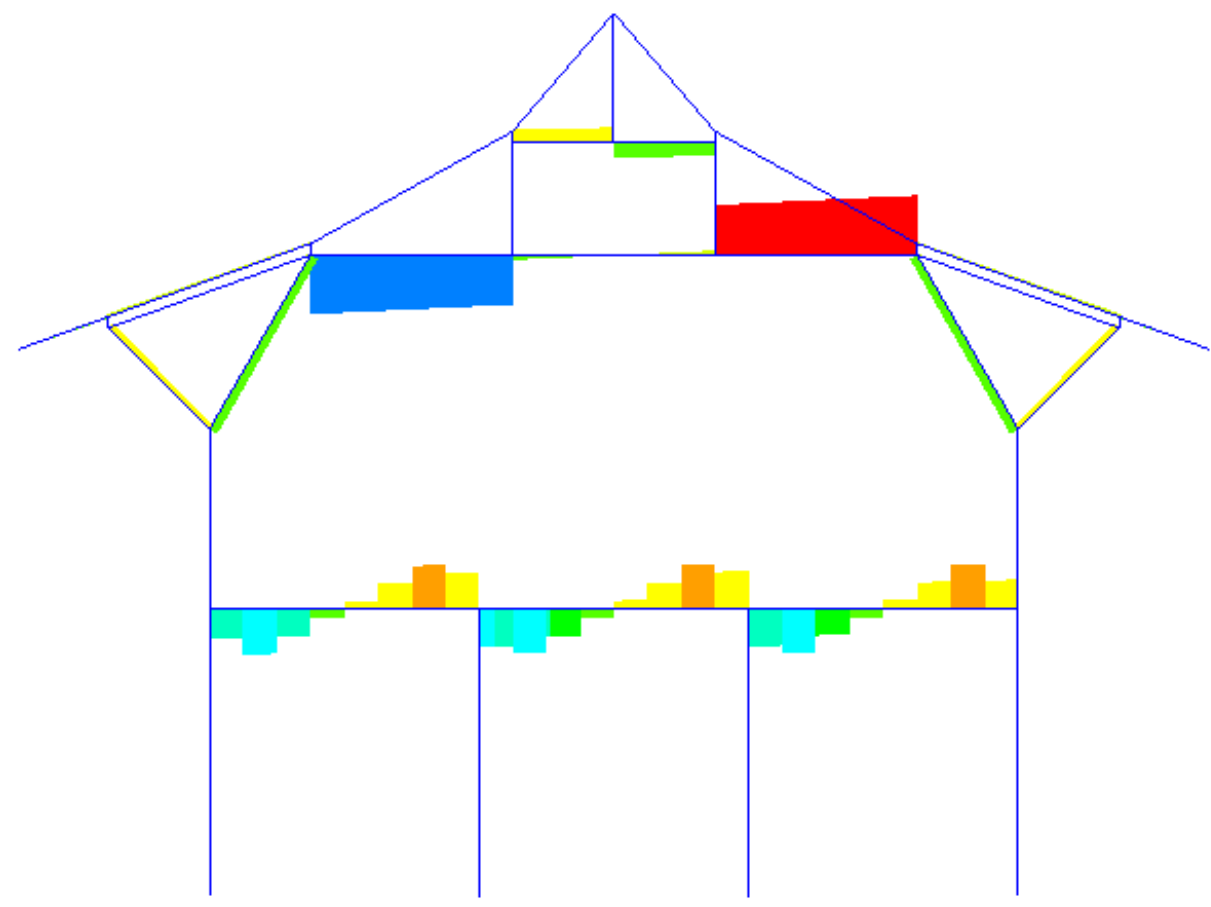

midas Gen POST-PROCESSOR BEAM DIAGRAM

SHEAR-z

$4.52152 \mathrm{e}+001$

3. $70151 \mathrm{e}+001$

$2.88150 \mathrm{e}+001$

2. $06149 \mathrm{e}+001$

$1.24149 \mathrm{e}+001$

$4.21475 \mathrm{e}+000$

$0.00000 \mathrm{e}+000$

$-1.21854 \mathrm{e}+001$

$-2.03855 e+001$

$-2.85856 \mathrm{e}+001$

$-3.67857 \mathrm{e}+001$

$-4.49858 \mathrm{e}+001$

CB: $\mathrm{LC} 2(\mathrm{SW}+\mathrm{DL}+\mathrm{R} \sim$

MAX : 197

MIN : 187

FILE: 20181007

UNIT: $\mathrm{kN}$

DATE: $04 / 13 / 2020$

VIEW-DIRECTION

$\mathrm{X}: 1.000$

Y: 0.000

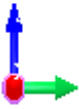

(D) Shear force diagram of $2^{\text {nd }}$ story part

Figure 6. Member forces of test-bed large-span Hanok 


\section{Structural Design of the Test-bed Large-span Hanok}

From Table 2 to Table 4, results of the structural design for the target members are shown. Table 2 and Table 3 show the structural design of main members of $1^{\text {st }}$ story part both in $\mathrm{Y}$ and $\mathrm{X}$ direction, respectively. Table 4 and Table 5 show the structural design of main members of $2^{\text {nd }}$ story part both in $\mathrm{Y}$ and $\mathrm{X}$ direction, respectively. The structural design was done for both raw wood and glulam. The target of the structural design is to extract optimal section size, that is, minimum width and depth of each member under condition of satisfying safety and serviceability conditions. The shape of the section is assumed rectangular. Safety condition is to satisfy both flexural and shear stress requirements, and serviceability condition is to satisfy deflection requirement. The comparison of the sectional area between raw wood and glulam shows that glulam requires less sectional area than raw wood. The area ratio of the glulam compared to the raw wood is from 0.60 to 0.92 in this test-bed Hanok. This result shows that, for the case of large-span Hanok it is more economical to use glulam than raw wood just from the viewpoint of the required volume size of the timber which affects much in cost and construction.

Table 2. Structural Design of Main Members of $1^{\text {st }}$ Story Part in Y direction

\begin{tabular}{|c|c|c|c|c|c|c|}
\hline \multirow{2}{*}{ Wood type } & Member & $\begin{array}{c}\text { Section } \\
\text { (width } \times \text { depth) }\end{array}$ & Flexural stress ratio & Shear stress ratio & Deflection ratio & $\begin{array}{c}\text { Area ratio } \\
\text { (Glulam / Raw wood) }\end{array}$ \\
\hline \multirow{2}{*}{$\begin{array}{c}\text { Raw wood } \\
\text { Grade 1 Larch }\end{array}$} & Main girder & $510 \times 810$ & $93.3 \%$ & $38.2 \%$ & $67.1 \%$ & - \\
\cline { 2 - 7 } & Middle girder & $420 \times 660$ & $99.0 \%$ & $23.6 \%$ & $36.1 \%$ & - \\
\cline { 2 - 7 } & Coller girder & $210 \times 360$ & $87.1 \%$ & $34.0 \%$ & $19.4 \%$ & - \\
\hline \multirow{2}{*}{$\begin{array}{c}\text { Glulam } \\
\text { 17S-49B }\end{array}$} & Main girder & $480 \times 720$ & $59.6 \%$ & $28.7 \%$ & $95.3 \%$ & 0.84 \\
\cline { 2 - 7 } & Middle girder & $330 \times 540$ & $89.4 \%$ & $23.0 \%$ & $78.7 \%$ & 0.84 \\
\cline { 2 - 7 } & Coller girder & $180 \times 270$ & $85.7 \%$ & $33.0 \%$ & $50.3 \%$ & 0.64 \\
\hline
\end{tabular}

Table 3. Structural Design of Main Members of $1^{\text {st }}$ Story Part in $\mathrm{X}$ direction

\begin{tabular}{|c|c|c|c|c|c|c|}
\hline \multirow{2}{*}{ Wood type } & Member & $\begin{array}{c}\text { Section } \\
\text { (width } \times \text { depth) }\end{array}$ & $\begin{array}{c}\text { Flexural stress } \\
\text { ratio }\end{array}$ & $\begin{array}{c}\text { Shear stress } \\
\text { ratio }\end{array}$ & $\begin{array}{c}\text { Deflection } \\
\text { ratio }\end{array}$ & $\begin{array}{c}\text { Area ratio } \\
\text { (Glulam / Raw wood) }\end{array}$ \\
\hline \multirow{4}{*}{$\begin{array}{c}\text { Raw wood } \\
\text { Grade 1 Larch }\end{array}$} & Ridge & $210 \times 330$ & $88.8 \%$ & $36.8 \%$ & $46.3 \%$ & - \\
\cline { 2 - 7 } & Middle-upper purlin & $210 \times 360$ & $95.1 \%$ & $43.1 \%$ & $45.4 \%$ & - \\
\cline { 2 - 7 } & Middle-lower purlin & $210 \times 360$ & $96.8 \%$ & $43.8 \%$ & $46.3 \%$ & - \\
\hline \multirow{3}{*}{$\begin{array}{c}\text { Glulam } \\
\text { 17S-49B }\end{array}$} & Column purlin & $270 \times 420$ & $89.2 \%$ & $47.2 \%$ & $36.6 \%$ & - \\
\cline { 2 - 7 } & Middle-upper purlin & $180 \times 300$ & $75.9 \%$ & $37.8 \%$ & $79.8 \%$ & 0.91 \\
\cline { 2 - 7 } & Middle-lower purlin & $180 \times 300$ & $77.3 \%$ & $38.7 \%$ & $81.3 \%$ & 0.71 \\
\cline { 2 - 7 } & Column purlin & $210 \times 330$ & $88.3 \%$ & $48.7 \%$ & $84.4 \%$ & 0.79 \\
\hline
\end{tabular}

Table 4. Structural Design of Main Members of $2^{\text {nd }}$ Story Part in Y direction

\begin{tabular}{|c|c|c|c|c|c|c|}
\hline Wood type & Member & $\begin{array}{c}\text { Section } \\
\text { (width } \times \text { depth) }\end{array}$ & $\begin{array}{c}\text { Flexural stress } \\
\text { ratio }\end{array}$ & $\begin{array}{c}\text { Shear stress } \\
\text { ratio }\end{array}$ & $\begin{array}{c}\text { Deflection } \\
\text { ratio }\end{array}$ & $\begin{array}{c}\text { Area ratio } \\
\text { (Glulam / Raw wood) }\end{array}$ \\
\hline \multirow{2}{*}{$\begin{array}{c}\text { Raw wood } \\
\text { Grade 1 Larch }\end{array}$} & Main girder & $510 \times 810$ & $99.5 \%$ & $34.0 \%$ & $48.6 \%$ & - \\
\cline { 2 - 7 } & Coller girder & $270 \times 450$ & $90.3 \%$ & $34.0 \%$ & $20.7 \%$ & - \\
\hline \multirow{2}{*}{$\begin{array}{c}\text { Glulam } \\
\text { 17S-49B }\end{array}$} & Main girder & $420 \times 690$ & $79.2 \%$ & $30.4 \%$ & $89.6 \%$ & 0.70 \\
\cline { 2 - 7 } & Coller girder & $210 \times 360$ & $86.2 \%$ & $34.4 \%$ & $48.8 \%$ & 0.62 \\
\hline
\end{tabular}


Table 5. Structural Design of Main Members of $2^{\text {nd }}$ Story Part in X direction

\begin{tabular}{|c|c|c|c|c|c|c|}
\hline \multirow{2}{*}{ Wood type } & Member & $\begin{array}{c}\text { Section } \\
\text { (width } \times \text { depth) }\end{array}$ & $\begin{array}{c}\text { Flexural stress } \\
\text { ratio }\end{array}$ & $\begin{array}{c}\text { Shear stress } \\
\text { ratio }\end{array}$ & $\begin{array}{c}\text { Deflection } \\
\text { ratio }\end{array}$ & $\begin{array}{c}\text { Area ratio } \\
\text { (Glulam / Raw wood) }\end{array}$ \\
\hline \multirow{4}{*}{$\begin{array}{c}\text { Raw wood } \\
\text { Grade 1 Larch }\end{array}$} & Ridge & $210 \times 330$ & $88.8 \%$ & $36.8 \%$ & $46.3 \%$ & - \\
\cline { 2 - 7 } & Middle purlin & $210 \times 360$ & $95.1 \%$ & $43.1 \%$ & $45.4 \%$ & - \\
\cline { 2 - 7 } & Column inner purlin & $240 \times 390$ & $96.5 \%$ & $47.2 \%$ & $42.5 \%$ & - \\
\hline \multirow{3}{*}{$\begin{array}{c}\text { Glulam } \\
\text { 17S-49B }\end{array}$} & Column outer purlin & $300 \times 480$ & $91.0 \%$ & $54.9 \%$ & $32.6 \%$ & - \\
\cline { 2 - 7 } & Middle purlin & $210 \times 330$ & $81.2 \%$ & $44.8 \%$ & $77.6 \%$ & 0.91 \\
\cline { 2 - 7 } & Inner purlin & $210 \times 300$ & $88.5 \%$ & $44.4 \%$ & $93.0 \%$ & 0.92 \\
\hline
\end{tabular}

\section{Conceptual Seismic Design of the Test-bed Large-span Hanok}

In this section, conceptual seismic design of the test-bed Hanok is discussed. Three methods are proposed, that is, addition of shear wall, reinforcing existing shear wall and applying seismic isolation technique. Fig. 7A and Fig. 7B show addition of shear wall to reinforce lateral resistance. Shear walls should be placed both in X and Y directions and as symmetrically as possible. Fig. 7C shows reinforcing existing shear wall by adding partial bracing which can help to increase ductility of the wall and hence to increase the overall seismic resistance capacity of the structure. Fig. 7D shows base isolation device installed between the base of the Hanok and the ground. By installing base isolation device, the transfer of the vibration of the ground to the structure can be mitigated and hence to reduce the seismic force transferred to the structure.

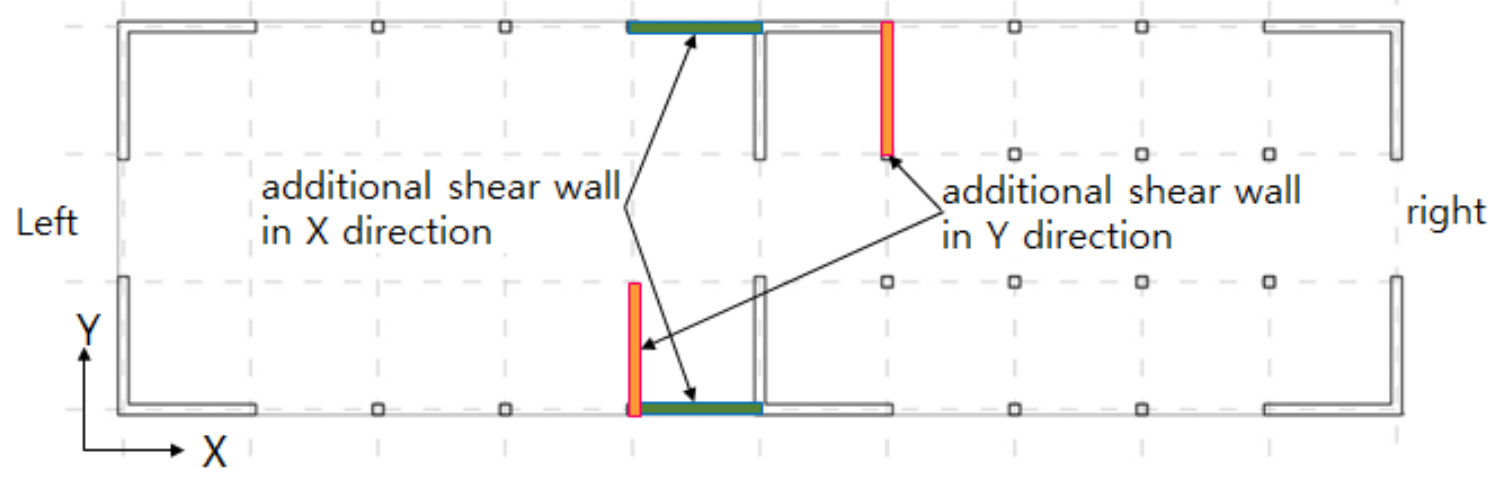

(A) Addition of shear wall in plan view

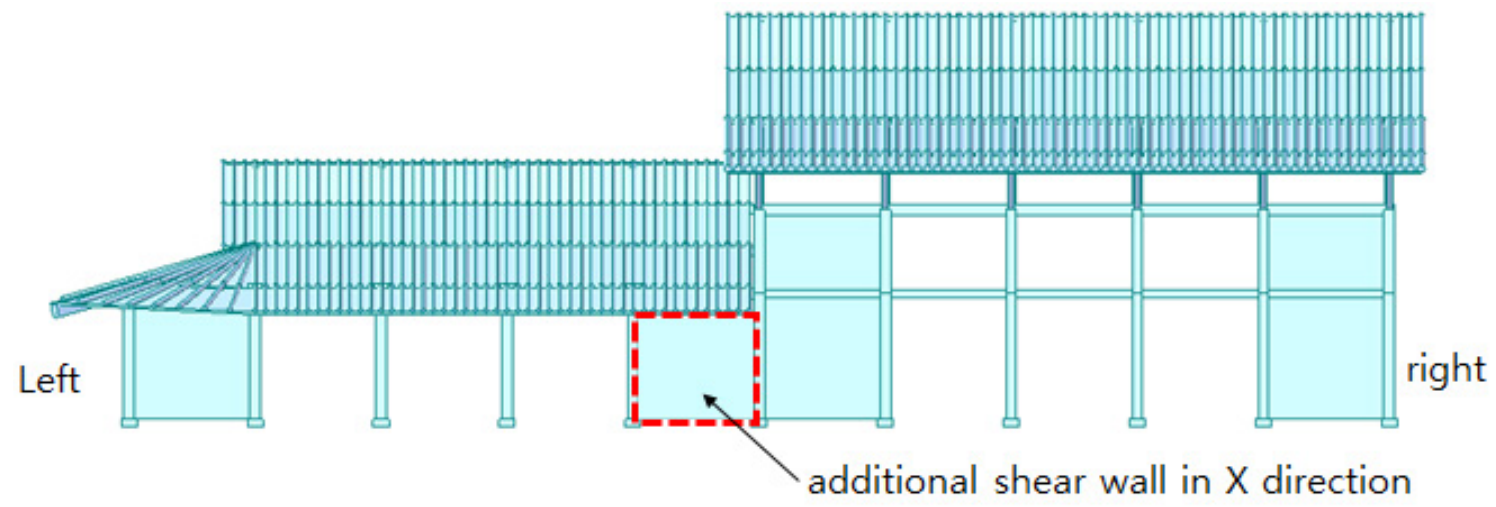

(B) Addition of shear wall in elevation view 

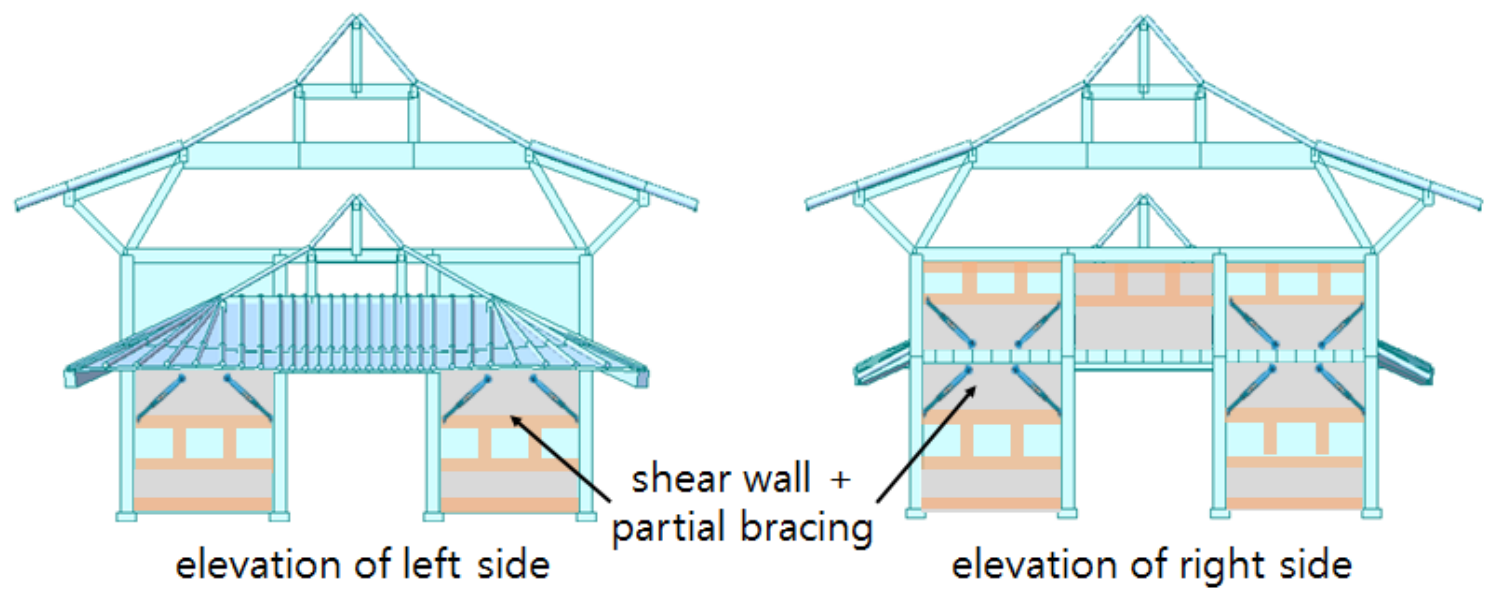

(C) Combination of shear wall and partial bracing

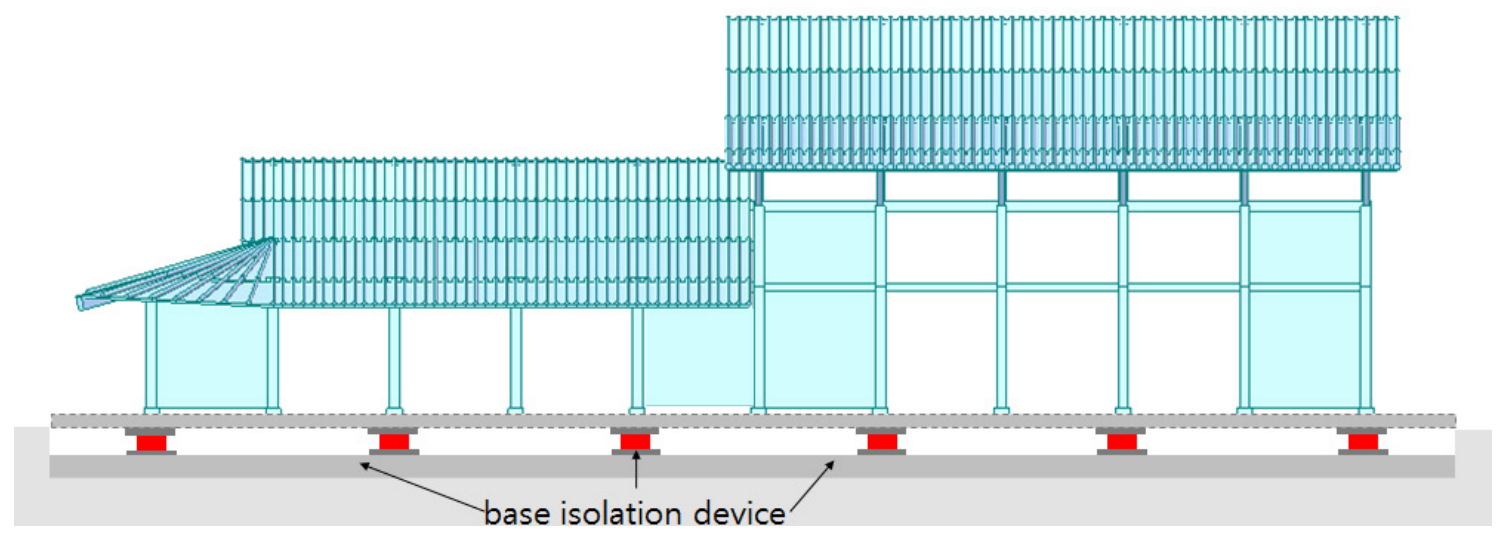

(D) Seismic isolation by using base isolation device

Figure 7. Recommendation of seismic design for large-span Hanok

\section{Conclusions}

In this study, a test-bed large-span Hanok has been introduced, and the structural analysis and seismic design for it has been performed to test possibility as a large-span Hanok. The test-bed Hanok consists of two parts, that is, 1st story part and 2nd story part. The two parts are joined together side by side. The largest span of this structure is $14.4 \mathrm{~m}$. The structural design was done to extract optimal section size for both raw wood and glulam under condition of satisfying safety and serviceability conditions. The comparison of the sectional area between raw wood and glulam showed that glulam required less sectional area than raw wood. The area ratio of the glulam compared to the raw wood is from 0.60 to 0.92 . This result shows that, it is more economical to use glulam than raw wood in large-span Hanok just from the viewpoint of the required volume size of the timber which affects much in cost and construction. In addition, seismic design concept for the test-bed large-span Hanok was proposed, that is, in addition to shear wall, reinforcing existing shear wall and introducing seismic isolation technique and the structural characteristics were discussed.

\section{Acknowledgements}

This work was supported by a grant (20AUDP-B128638-04) from Urban and Architecture Research Program funded by Ministry of Land, Infrastructure and Transport Affairs of Korean Government.

\section{REFERENCES}

[1] Y.M. Kim, Monitoring of Moisture Contents in Korean Traditional Wooden Houses. In Proceedings of the World Congress on Engineering 2014, London, England, 1298-1303, 2014.

[2] Y. M. Kim. Monitoring of Vertical Deflection and Moisture Contents in Korean Traditional Timber Houses, Civil Engineering and Architecture, Vol. 3, No. 5, 107-120, 2015.

[3] Philipp, D., Andreas, G., Michael, M., Stefan, W. Monitoring of Building Climate and Timber Gradient in Large-span Timber Structures, Journal of Civil Structural Health Monitoring, Vol. 5, No. 2, 153-165, 2015.

[4] Y. M. Kim. Macroscopic Deformation Analysis of Hanok by 
Synthesizing Technique of Digital Images, Journal of the Architectural Institute of Korea: Structure \& Construction Section, Vol. 33, No. 10, 46-52, 2017.

[5] J. M. Seo, I. K. Choi, J. R. Lee, Static and Cyclic Behavior of Wooden Frames with Tenon Joints Under Lateral Load, Journal of Structural Engineering, Vol. 125, No. 3, 344-349, 1999.

[6] J. G. Hwang, S. G. Hong, Y. W. Lee, S. J. Jung, Natural Frequency Characteristics of Traditional Wooden Structure for Vibration Amplitude, Journal of the Architectural Institute of Korea : Structure \& Construction, Vol. 25, No. 5, 3-10, 2009.

[7] D. P. Fang, S. Iwasaki, M. H. Yu, Q. P. Shen, Y. Miyamoto, H. Hikosaka, Ancient Chinese Timber Architecture II : Dynamic Characteristics, Journal of Structural Engineering, Vol. 127, No. 11, 1358-1364, 2001.

[8] Y. M. Kim. Development of Automated Structural Design Tool for Horizontal Members of Hanok, Journal of the Architectural Institute of Korea: Structure \& Construction Section, Vol. 33, No. 4, 21-28, 2017.

[9] Y. M. Kim. Development of Structural Design Tool of Hanok Columns Considering Rotational Stiffness, Journal of the Architectural Institute of Korea: Structure \& Construction Section, Vol. 33, No. 8, 29-36, 2017.

[10] Y. M. Kim. An Evaluation Scheme of Torsional Irregularity for Seismic Design of Hanok, Journal of the Architectural Institute of Korea: Structure \& Construction Section, Vol. 35, No. 10, 191-198, 2019.

[11] B.S. Park, Y.M. Kim, M.W. Hur, S.H. Lee, Conceptual Application Schemes of Seismic Isolation Techniques to Hanok, Journal of the Architectural Institute of Korea : Structure \& Construction, vol. 36, No. 1, 137-146, 2020. 